\title{
The Effect of Aqueous Extract of Cecropia glazioui Snethlage (Embauba) in the Rat Fetal Development
}

\author{
Priscila Randazzo-Moura ${ }^{1,2}$, Magali Glauzer Silva ${ }^{1}$, Yoko Oshima-Franco ${ }^{1}$, \\ Francisco Carlos Groppo ${ }^{3}$, Marli Gerenutti ${ }^{{ }^{*}}$ \\ ${ }^{1}$ School of Pharmacy, University of Sorocaba, Sorocaba, Brazil \\ ${ }^{2}$ Pontifical Catholic University of Sorocaba, Sorocaba, Brasil \\ ${ }^{3}$ Piracicaba Dental School, State University of Campinas, Piracicaba, Brazil \\ E-mail: ${ }^{*}$ marli.gerenutti@prof.uniso.br \\ Received May 15, 2011; revised May 29, 2011; accepted June 8, 2011
}

\begin{abstract}
The effect of aqueous extract of Cecropia glazioui Snethlage (Embauba) in the rat fetal development. This study was to complement previous assays on the physical and neurobehavioral development of rats resulted from oral administration of $1 \mathrm{~g} / \mathrm{kg} /$ day Cecropia glazioui Snethlage (C. glazioui) aqueous extract (LD50 $>5$ $\mathrm{g} \cdot \mathrm{kg}^{-1}$ ) in pregnant rats (peri- and post-natal studies). In the present study, the effect of $2.5 \mathrm{~g} / \mathrm{kg} / \mathrm{week} C$. glazioui aqueous extract, administered to pregnant rats during 15 days, was verified in the rat offspring development. No acute or chronic toxicity (no effects on mortality or weight average daily gain) were observed. In addition, no effects on reproductive parameters (offspring vitality, placenta and fetus weight, number of corpora lutea on each ovary, pre- and post-implantation loss) and on offspring external morphology were found. We concluded that $C$. glazioui aqueous extract administered during pregnancy did not cause abnormalities in rat offspring.
\end{abstract}

Keywords: Fetuses’ Abnormalities, Medicinal Plants, Teratogenesis

\section{Introduction}

Several studies concerning the pharmacological effects of Cecropia glazioui Snethlage (Cecropiaceae), popularly known as "Embauba" in Brazil, were published in the last decade. The C. glazioui aqueous extract showed anxiolytic-like effect in mice [1], probable by blocking monoamines uptake in the central nervous system [2]. An anti-asthmatic property was confirmed in guinea pigs treated with C. glazioui purified fraction [3]. It also showed hypotensive activity [4], which is not related to angiotensin-converter enzyme [5], and it has antisecretory/antiulcer properties [6]. Plants are an important source of new molecules, which result mainly as consequence of their ontogenesis caused by internal and external forces [7]. They produce active primary and secondary metabolites to defend themselves against predators, microorganisms, and UV rays; and to attract seeddispersive animals and insects [8]. Some of C. glazioui constituents, such as catechins, procyanidins and flavonoids, were observed by Tanae et al. [9]. Brazilian legal requirements of phytotherapics' marketing demand data on their pharmacological action and therapeutic efficacy. Safety is other legal aspect regarding phytotherapics [10-15]. However, few studies on phytotherapic safety are available in the literature and data regarding $C$. glazioui toxicity is still scarce. A previous study showed that the daily exposure to $1 \mathrm{~g} / \mathrm{kg} \mathrm{C}$. glazioui aqueous extract showed low toxicity to pregnant rats and their litters [16]. The objective of the present study was to evaluate the influence of weekly oral administration of $C$. glazioui aqueous extract $(2.5 \mathrm{~g} / \mathrm{kg})$ in pregnant rats, simulating the human sporadic use.

\section{Material and Methods}

\subsection{Plants}

The Cecropia glazioui Snethlage specimen were collected in Tapirai city (State of São Paulo, Brazil). A voucher specimen is deposited in University of Sorocaba (UNISO) herbarium, being identified by Dr Sérgio Romaniuc Neto (Botanic Institute of São Paulo, Brazil). 


\subsection{Preparation of the Aqueous Extract}

Fresh leaves (450 g) of C. glazioui without petiole were dried, powdered and a $70 \%$ hydroalcoholic extract was obtained by percolation. The extract was concentrated under reduced pressure and lyophilized providing 102.3 $\mathrm{g}$ of powder (efficiency $=22.7 \%$ ). It was stored at room temperature without light and humidity until the toxicological assays were performed. The C. glazioui aqueous extract was freshly prepared in distillated/deionizated water before oral administration.

\subsection{Animals}

Wistar rats $(160-200 \mathrm{~g})$ of both genders were obtained and kept at UNISO/Pharmacy School facilities according to "The Guide for the Care and Use of Laboratory Animal" (National Research Council 1996) and "European Community Guidelines" (EEC Directive of 1986; 86/609/EEC). All animals were maintained in groups (5 6 rats/cage) with food and water ad libitum. A twelvehour light/dark cycle at constant temperature $\left(23^{\circ} \mathrm{C} \pm\right.$ $1^{\circ} \mathrm{C}$ ) was observed. All animals were previously adapted to laboratory conditions during one week before the experiments. The study design was approved by the UNISO Ethical Committee for Experiments.

\subsection{Reproductive Ability Evaluation}

Twelve sexually-naive rat females were mated with rat males (five females and one male per cage). Pregnancy was confirmed through the presence of spermatozoids in vaginal-washing rubbing observed by microscopy analysis [17]. The presence of spermatozoids was considered as the first day of pregnancy. Pregnant females were kept in separate cages. At the $1^{\text {st }}, 5^{\text {th }}, 10^{\text {th }}$ and $15^{\text {th }}$ days of pregnancy, six females received $2.5 \mathrm{~mL} / \mathrm{kg}$ of deionized water by gavage (control group) and six females received $2.5 \mathrm{~g} / \mathrm{kg}$ of C. glazioui solution by gavage (treated group). According to Gerenutti et al. [16], this C. glazioui dose is non-toxic for adult female rats. The posology of $C$. glazioui was based on rat-fetus development (in days from ovulation): blastocyst formation-3 to 5 days; implantation -5 to 6 days; organogenesis -7 to 17 days [18]. The weight gain of the pregnant rats exposed to any chemical agent during a specific period is one of the most used parameters to determine toxicological effects $[19,20]$. At the $18^{\text {th }}$ day of pregnancy, each rat female was anesthetized by halothane (Halotano ${ }^{\circledR}$, Cristalia, Brazil) inhalation and the uterus was rapidly excised. The following macroscopic parameters were evaluated in order to observe the reproductive performance [20,21]:

1) Offspring vitality;
2) Placenta and fetus weight (grams);

3) The number of corpora lutea on each ovary;

4) Pre-implantation loss $(\%)=$ corpora lutea number implantation number/corpora lutea number

5) Post-implantation loss (\%) = implantation number alive fetus number/implantation number

Afterward, offspring animals were killed by halothane inhalation, fixed in Bouin's solution for $24-48 \mathrm{~h}$, and kept in $70 \%$ hydroalcoholic solution in order to measure the following parameters (in $\mathrm{cm}$ ): antero-posterior (A) and latero-lateral (B) of cranio; antero-posterior (C) and latero-lateral (D) of thorax; cranio-caudal (E) and tail (F), as showed in Figure 1.

\subsection{Statistical Analysis}

The data were analyzed by using Student's $t$ test. The significance level was set at $5 \%$. The results were expressed as mean \pm standard error mean (SEM).

\section{Results}

Figure 2 shows the body weight (in grams) gain during pregnancy and killing period $\left(18^{\text {th }}\right.$ day). At the $1^{\text {st }}$ day of pregnancy, the females of $C$. glazioui group showed lower $(p<0.05)$ body weight gain when compared to control group. There was no influence $(p>0.05)$ of $C$. glazioui in body weight in the further periods. No other changes, such as morbidity or mortality, were registered during the experimental period.

Figure 3 shows the weight of placenta and fetus. No statistically significant difference $(p>0.05)$ was observed between control and treated groups for both parameters.

The Table 1 shows the reproductive performance of pregnant rats exposed to C. glazioui $(n=6)$ compared to the control group $(n=6)$. C. glazioui did not influence $(p>$
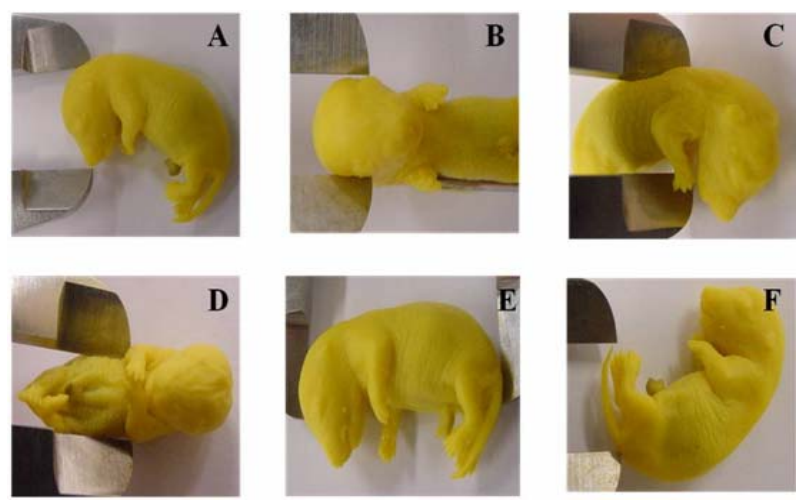

Figure 1. Measurement of external anatomy aspects: antero-posterior (A) and latero-lateral (B) of cranio; antero-posterior (C) and latero-lateral (D) of thorax; craniocaudal (E) and tail (F). 


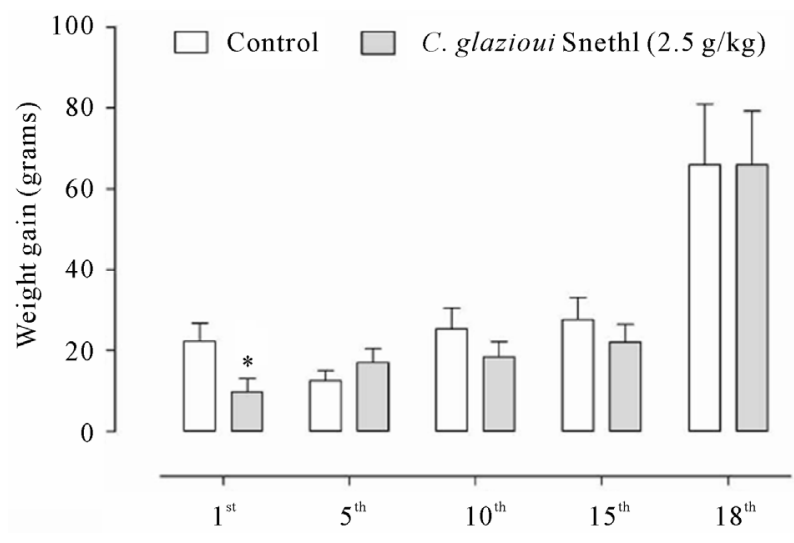

Figure 2. Mean ( \pm SEM) body weight gain (in grams) of both control and $C$. glazioui treated groups. $\left({ }^{*} p<0.05\right)$.

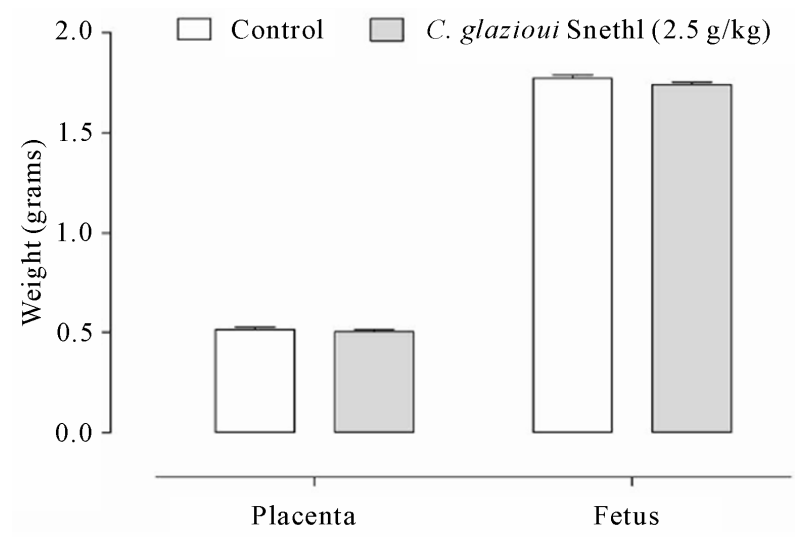

Figure 3. Mean ( \pm SEM) of weight gain of placenta and fetus. No statistically significant changes were observed between groups $(p>0.05)$.

Table 1. Reproductive performance of pregnant rats exposed to Cecropia glazioui Snethl aqueous extract.

\begin{tabular}{ccc}
\hline Parameters & Control group & C. glazioui $2.5 \mathrm{~g} / \mathrm{kg}$ \\
\hline Number of fetus & 63 & 64 \\
Number of corpora lutea & 73 & 67 \\
Pre-implantation loss (\%) & $0.38 \pm 0.31$ & $0.04 \pm 0.04$ \\
Post-implantation loss (\%) & 0 & 0 \\
Offspring vitality (\%) & 100 & 100 \\
\hline
\end{tabular}

0.05 ) any of the five reproductive performance parameters.

Figure 4 shows the measurement (in $\mathrm{cm}$ ) of offspring external anatomical parameters. No statistically significant difference between C. glazioui and control groups was observed regarding any of the measurements.

\section{Discussion}

Health governmental agencies and guidelines usually

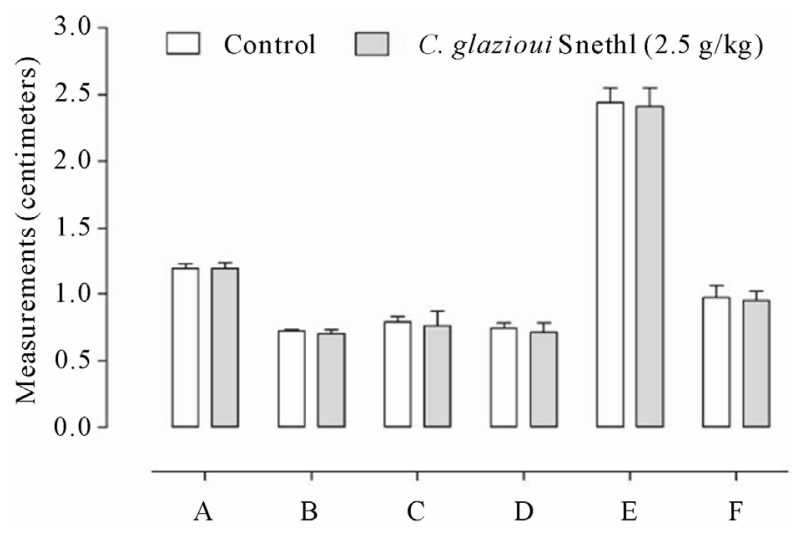

Figure 4. Offspring external morphological parameters (in cm): antero-posterior (A) and latero-lateral (B) of cranio; antero-posterior (C) and latero-lateral (D) of thorax; cranio-caudal (E) and tail (F). No statistically significant changes were observed between groups $(p>0.05)$.

require developmental and reproductive toxicology (DART) tests for drugs destined for human use. DART studies require at least one of three segments of reproductive cycle [18]: 1) premating and mating through implantation (reproduction and fertility studies); 2) from implantation through major organogenesis (teratology and/or development toxicological studies); 3) late pregnancy and post-natal development (the perinatal/postnatal studies). In the present study, the segment 2 was observed, while segment 3 was previously studied by Gerenutti et al. [16]. Those authors observed the effect of C. glazioui extract $(\mathrm{Cg})$ on physical and neurobehavioral development of rats. Female rats received $1 \mathrm{~g} / \mathrm{kg} /$ day of $\mathrm{Cg}$ during pregnancy and they observed that $\mathrm{LD}_{50}$ was higher than $5 \mathrm{~g} / \mathrm{kg}$. In addition, latency of uprightness and negative geotaxis reflexes were enhanced by $\mathrm{Cg}$ in comparison to the control group, but the rearing frequency decreased [18]. They concluded that Cg showed low toxicity to the pregnant rats and their litters, and these effects were similar to the anxiolytic-like effect observed in mice by Rocha et al. [1]. In our study, the second segment of reproductive cycle, commonly referred as the major period of organogenesis ( 6 to 15 days in rats), was focused in a new experimental design. This included the period from implantation to closure of the hard palate, being the $\mathrm{Cg}$ extract administered at critical points $\left(1^{\text {st }}, 5^{\text {th }}, 10^{\text {th }}\right.$ and $15^{\text {th }}$ days of pregnancy). No signs of morbidity, mortality or abortion were registered during the pregnancy period, and no evidence of chronic toxicity, food intake changes, or body weight gain (except at the $1^{\text {st }}$ day) was induced by $\mathrm{Cg}$, which is similar to the results observed by Gerenutti et al. [16]. Abnormalities are usually classified as malformations or developmental variations. Malformations are structural anomalies altering general body conformity, causing dis- 
ruption or interfering with body function, being generally incompatible with life. Developmental variations are defined as anatomical structure alterations having no significant biological effect on health or body conformity, usually representing slight deviations from normal [22]. Considering the offspring external morphological measurements in the present study, $\mathrm{Cg}$ extract did not induce significant effects in these measurements when compared with the control group. Studies carried out to establish the potential ability of drugs to induce adverse effects on the fetal development, which used acceptable and rationale experimental design, could provide accurate extrapolation of the potential risk in human beings of that particular drug. Considering the previous study performed by Gerenutti et al. [16], which used the same aqueous extract of $\mathrm{Cg}$, it was possible to conclude that Cecropia glazioui Snethlage presents no toxicity on morphological development of rat offspring.

\section{Acknowledgements}

This work was supported by UNISO. R-M, P. was student of Scientific Initiation from UNISO.

\section{References}

[1] F. F. Rocha, A. J. Lapa and T. C. de Lima, "Evaluation of the Anxiolytic-Like Effects of Cecropia glazioui Sneth in Mice," Pharmacology, Biochemistry and Behavior, Vol. 71, No. 1-2, 2002, pp. 183-190. doi:10.1016/S0091-3057(01)00695-5

[2] F. F. Rocha, M. T. Lima-Landman, M. M. Tanae, T. C. de Lima and A. J. Lapa, "Antidepressant-Like Effect of Cecropia glazioui Sneth and Its Constituents-In Vivo and in Vitro Characterization of the Underlying Mechanism," Phytomedicine, Vol. 14, No. 6, 2007, pp. 396-402. doi:10.1016/i.phymed.2007.03.011

[3] S. Delarcina, M. T. Lima-Landman, C. Souccar, R. M. Cysneiros, M. M. Tanae and A. J. Lapa, "Inhibition of Histamine-Induced Bronchospasm in Guinea Pigs Treated with Cecropia glaziovi Sneth and Correlation with the in Vitro Activity in Tracheal Muscles," Phytomedicine, Vol. 14, No. 5, 2007, pp. 328-332. doi:10.1016/j.phymed.2006.12.022

[4] M. T. Lima-Landman, A. C. Borges, R. M. Cysneiros, T. C. de Lima, C. Souccar and A. J. Lapa, "Antihypertensive Effect of a Standardized Aqueous Extract of Cecropia glaziovii Sneth in Rats: An in Vivo Approach to the Hypotensive Mechanism," Phytomedicine, Vol. 14, No. 5, 2007, pp. 314-320. doi:10.1016/j.phymed.2007.03.003

[5] M. F. Ninahuaman, C. Souccar, A. J. Lapa and M. T. Lima-Landman, "ACE Activity during the Hypotension Produced by Standardized Aqueous Extract of Cecropia glaziovii Sneth: A Comparative Study to Captopril Effects in Rats," Phytomedicine, Vol. 14, No. 5, 2007, pp. 321-327. doi:10.1016/i.phymed.2006.12.010
[6] C. Souccar, R. M. Cysneiros, M. M. Tanae, L. M. Torres, M. T. Lima-Landman and A. J. Lapa, "Inhibition of Gastric Acid Secretion by a Standardization Aqueous Extract of Cecropia glaziovii Sneth and Underlying Mechanism," Phytomedicine, Vol. 15, No. 6-7, 2008, pp. 462-469. doi:10.1016/j.phymed.2008.02.006

[7] R. Lewontin, "It Ain't Necessarily So: The Dream of the Human Genome and Other Illusions," New York Review Books, New York, 2000.

[8] M. Wink, "Physiology of Secondary Product Formation in Plants," In: B. V. Charwood and M. J. C. Rhodes, Eds., Secondary Products from Plant Tissue Culture, Clarendon, Oxford, 1990, pp. 67-86.

[9] M. M. Tanae, M. T. Lima-Landman, T. C. de Lima, C. Souccar and A. J. Lapa, "Chemical Standardization of the Aqueous Extract of Cecropia glaziovii Sneth Endowed with Antihypertensive, Brochodilator, Antiacid Secretion and Antidepressant-Like Activities," Phytomedicine, Vol. 14, No. 5, 2007, pp. 309-313. doi:10.1016/j.phymed.2007.03.002

[10] Brasil, Ministério da Saúde, Agência Nacional de Vigilância Sanitária, Resolução de Diretoria Colegiada 48, Diário Oficial da União, Brasília, 2004.

[11] Brasil, Ministério da Saúde, Agência Nacional de Vigilância Sanitária, Resolução 88, Diário Oficial da União, Brasília, 2004.

[12] Brasil, Ministério da Saúde, Agência Nacional de Vigilância Sanitária, Resolução 89, Diário Oficial da União, Brasília, 2004.

[13] Brasil, Ministério da Saúde, Agência Nacional de Vigilância Sanitária, Resolução 90, Diário Oficial da União, Brasília, 2004.

[14] Brasil, Ministério da Saúde, Agência Nacional de Vigilância Sanitária, Resolução 91, Diário Oficial da União, Brasília, 2004.

[15] Brasil, Presidência da República, Decreto 5813, Diário Oficial da União, Brasília, 2006.

[16] M. Gerenutti, A. F. Prestes, M. G. Silva, F. de S. Del Fiol, Y. O. Franco, P. C. Venâncio and F. C. Groppo, "The Effect of Cecropia glazioui Snethlage on the Physical and Neurobehavioral Development of Rats," Pharmazie, Vol. 63, No. 5, 2008, pp. 398-404.

[17] B. H. Vickery and J. P. Bennett, "Rats and Mice," In: E. S. E. Hafez, Ed., Reproduction and Breeding Techniques for Laboratory Animals, Lea \& Febiger, Philadelphia, 1970, pp. 299-315.

[18] K. A. Keller, "Developmental and Reproductive Toxicology," In: D. Jacobson-Kram and K. A. Keller, Eds., Toxicology Testing Handbook: Principles, Applications and Data Interpretation, Marcel Dekker, Inc., New York, 2001, pp. 195-254.

[19] M. Gerenutti, A. H. de-Souza Spinosa and M. M. Bernardi, "Effects of Bracken Fern (Pteridium aquilinum L. Kuhn) Feeding during the Development of Female Rats and Their Offspring," Veterinary and Human Toxicology, Vol. 34, No. 4, 1992, pp. 307-310.

[20] M. Gerenutti, F. Del Fiol and F. C. Groppo, "Reproduc- 
tive Performance of Pregnant Rats and Embryotoxic Effects of Ciprofloxacin," Pharmazie, Vol. 61, No. 1, 2006, pp. 79-80.

[21] W. F. Rayburn, H. D. Christensen and C. L. Gonzalez, "Effect of Antenatal Exposure to Saint John's Wort (Hypericum) on Neurobehavior of Developing Mice," American Journal of Obstetrics and Gynecology, Vol. 183,
No. 5, 2000, pp. 1225-1231.

doi: $10.1067 / \mathrm{mob} .2000 .108889$

[22] US EPA, "Guidelines for the Health Assessment of Suspected Developmental Toxicants," Federal Register 51: 34028, 1986; Proposed Amendments Federal Register 54:9386, 1989. 